


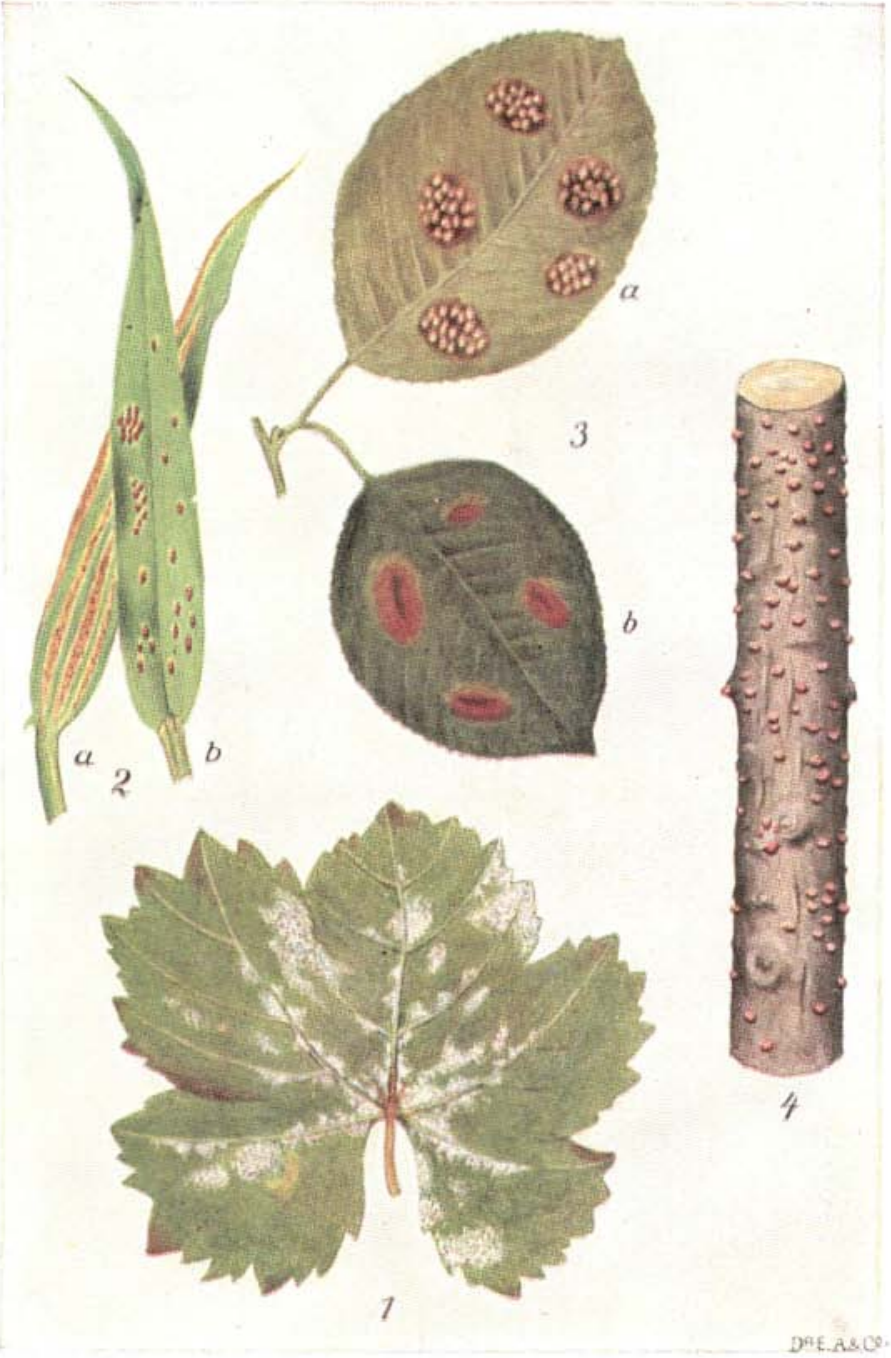

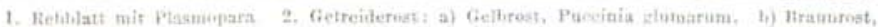

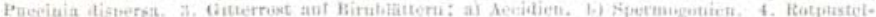

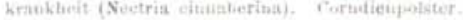




\section{Sammlung Bsöjhen}

\section{Pflanzenfranffheiten}

Bon

\section{Dr. Berner \&riedrid Brut \\ in Sieß̧en}

Mit einer farbigen $\mathfrak{T a f e l}$

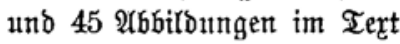

\section{Seipzig}

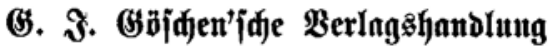


Ulte Redte, insbefonbere bas thberfegungstedt, oon ber Berlagsbanblung vorbebalten.

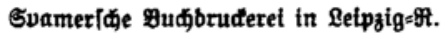

